Pacific Journal of Mathematic 


\section{FUNCTIONS REPRESENTED BY RADEMACHER SERIES}

\section{JAMES R. MCLAUGHLIN}

A series of the form $\sum_{m=1}^{\infty} a_{m} r_{m}(t)$, where $\left\{a_{m}\right\}$ is a sequence of real numbers and $r_{m}(t)$ denotes the $m$ th Rademacher function, sign $\sin \left(2^{m} \pi t\right.$ ), is called a Rademacher series (as usual, sign $0=0$ ).

Letting $f(t)$ denote the sum of this series whenever it exists, we shall investigate the effect that various conditions on $\left\{a_{m}\right\}$ have on the continuity, variation, and differentiability properties of $f$.

2. Continuity properties. We now prove

THEOREM (2.1). If $\sum\left|a_{m}\right|<\infty$, then $f(t)$ is continuous at dyadic irrationals (i.e., numbers not of the form $p / 2^{k}$ ) and has right and left hand limits everywhere in $[0,1]$.

Proof. Under our hypothesis we have that $\sum a_{m} r_{m}(t)$ converges uniformly to $f(t)$, which implies our conclusion since the Rademacher functions are continuous at dyadic irrationals and have right and left hand limits everywhere in $[0,1]$.

In general, the right and left hand limits of $f(t)$ are unequal at dyadic rationals. We now investigate under what conditions we have equality and prove.

THEOREM (2.2). If $\sum\left|a_{m}\right|<\infty$, then the following are equivalent:

(a) $a_{k}=\sum_{m=k+1}^{\infty} a_{m}$,

(b) $f\left(p 2^{-k}+\varepsilon_{n}\right) \rightarrow f\left(p 2^{-k}\right)$ as $n \rightarrow \infty$,

(c) $f\left(p 2^{-k}+\delta_{n}\right) \rightarrow f\left(p 2^{-k}\right)$ as $n \rightarrow \infty$,

(d) $f\left(p 2^{-k}+\varepsilon_{n}\right)-f\left(p 2^{-k}+\delta_{n}\right) \rightarrow 0$ as $n \rightarrow \infty$,

where $\left\{\varepsilon_{n}\right\}$ and $\left\{\delta_{n}\right\}$ are some positive and negative sequences tending to zero, and $p$ is an odd integer.

Proof.

$$
\begin{aligned}
f\left(p 2^{-k}+t\right)-f\left(p 2^{-k}\right)= & \sum_{m=1}^{k-1} a_{m} r_{m}\left(p 2^{-k}+t\right)-a_{k} r_{k}(t) \\
& +\sum_{m=k+1}^{\infty} a_{m} r_{m}(t)-\sum_{m=1}^{k-1} a_{m} r_{m}\left(p 2^{-k}\right),
\end{aligned}
$$

since $r_{m}\left(p 2^{-k}+t\right)=r_{m}(t)$ if $m \geqq k+1$, and $r_{k}\left(p 2^{-k}+t\right)=-r_{k}(t)$. 
Therefore,

$$
f\left(p 2^{-k}+\varepsilon_{n}\right)-f\left(p 2^{-k}\right) \rightarrow-a_{k}+\sum_{m=k+1}^{\infty} a_{m} \text { as } n \rightarrow \infty .
$$

This shows the equivalence of (a) and (b). A similar argument. establishes the equivalence of (a), (c), and (d).

We have, at once, the following

COROLlaRy (2.1). For absolutely convergent Rademacher series the following are equivalent:

(i) $f(t)$ is continuous at $p 2^{-k}$ for some odd integer $p$,

(ii) $f(t)$ is continuous at $p 2^{-k}$ for all odd integers $p$,

(iii) $a_{k}=\sum_{m=k+1}^{\infty} a_{m}$.

REMARKs. 1. Notice that, if $a_{k}=\sum_{m=k+1}^{\infty} a_{m}$ and $a_{k+1}=\sum_{m=k+2}^{\infty} a_{m}$, then $a_{k+1}=\left(a_{k}\right) / 2$.

2. Theorem (2.2) is false under the hypothesis that $\sum\left|a_{m}\right|=\infty$ and $a_{m} \rightarrow 0$, since under these conditions we have that in every interval $f(t)$ assumes every real number $c$ times [2, p. 234, Th. 2].

This shows that the existence of the limit in the sense of Theorem (2.2) implies no relationship whatever between $a_{k}$ and $\sum_{m=k+1}^{\infty} a_{m}$. Also by choosing $\left\{a_{m}\right\}$ such that $\sum\left(a_{m}\right)^{2}=\infty$ we see that the existence of the limit in the above sense does not even imply that $\sum a_{m} r_{m}(t)$ converges in a set of positive measure [8, p. 212]. (see [3]).

3. If $f(t)=\sum a_{m} r_{m}(t)$ is essentially bounded, then $\sum\left|a_{m}\right|<\infty$

We now omit the condition that $\sum\left|a_{m}\right|<\infty$ and prove

THEOREM (2.3) $a_{k}=\left(a_{k-1}\right) / 2, k>1$, if either

$$
\begin{aligned}
& \lim _{n \rightarrow \infty}\left[f\left(2^{-k}+p 2^{-k+2}+\varepsilon_{n}\right)-f\left(2^{-k+1}+p 2^{-k+2}+\varepsilon_{n}\right)\right] \\
= & \lim _{n \rightarrow \infty}\left[f\left(2^{-k}+p 2^{-k+2}+\delta_{n}\right)-f\left(2^{-k+1}+p 2^{-k+2}+\delta_{n}\right)\right]
\end{aligned}
$$

or

$$
\begin{aligned}
& \lim _{n \rightarrow \infty}\left[f\left(2^{-k+1}+p 2^{-k+2}+\varepsilon_{n}\right)=f\left(3 \cdot 2^{-k}+p 2^{-k+2}+\varepsilon_{n}\right)\right] \\
= & \lim _{n \rightarrow \infty}\left[f\left(2^{-k+1}+p 2^{-k+2}+\delta_{n}\right)-f\left(3 \cdot 2^{-k}+p 2^{-k+2}+\delta_{n}\right)\right]
\end{aligned}
$$

where $\varepsilon_{n}>0, \delta_{n}<0, \lim \varepsilon_{n}=\lim \delta_{n}=0$ and $p$ is an interger.

Proof. If $k>1, \Delta(t)$ 


$$
\begin{aligned}
\equiv & f\left(2^{-k}+p 2^{-k+2}+t\right)-f\left(2^{-k+1}+p 2^{-k+2}+t\right) \\
= & a_{1}\left[r_{1}\left(2^{-k}+p 2^{-k+2}+t\right)-r_{1}\left(2^{-k+1}+p 2^{-k+2}+t\right)\right]+\cdots \\
& +a_{k-2}\left[r_{k-2}\left(2^{-k}+p 2^{-k+2}+t\right)-r_{k-2}\left(2^{-k+1}+p 2^{-k+2}+t\right)\right] \\
& +a_{k-1}\left[r_{k-1}\left(2^{-k}+t\right)+r_{k-1}(t)\right]+a_{k}\left[-r_{k}(t)-r_{k}(t)\right] .
\end{aligned}
$$

Thus,

$$
\lim _{n \rightarrow \infty} \Delta\left(\varepsilon_{n}\right)=2 a_{k-1}-2 a_{k} \text { and } \lim _{n \rightarrow \infty} \Delta\left(\delta_{n}\right)=2 a_{k} .
$$

In view of (1) we have then $2 a_{k}=a_{k-1}$.

A similar proof will suffice if equation (2) is valid.

REMARK. In much the same way we can prove a more general result, namely that if $\left\{c_{k}\right\}$ has the property that

$$
\sum_{m=1}^{\infty} 1 / \prod_{k=1}^{m}\left(1+c_{k}\right)=c^{-1} \neq 0
$$

is absolutely convergent, then

$$
f(t)=c f(0+) \sum_{m=1}^{\infty} r_{m}(t) / \prod_{k=1}^{m}\left(1+c_{k}\right)
$$

if and only if for every $k>1$ we have that in (1) the first limit equals $e_{k}$ times the second.

We now utilize the concepts of approximate limits and approximately continuous functions (see [5, pp. 132, 219]). From Theorem (2.3), we deduce immediately.

COROLLARY 2.2. If the approximate limit of $f(t)$ exists at either $2^{-k}+p 2^{-k+2}$ and $2^{-k+1}+p 2^{-k+2}$ or $2^{-k+1}+p 2^{-k+2}$ and $3 \cdot 2^{-k}+p 2^{-k+2}$ (where $k>1$ and $p$ is any integer), then $a_{k}=\left(a_{k-1}\right) / 2$.

We now prove

COROLlaRY (2.3). If $F(t)$ is approximately continuous in $[0,1]$ and $\sum a_{m} r_{m}(t)$ converges a.e. in $[0,1]$ to $F(t)$, then

$$
F(t)=F(0) \cdot(1-2 t), a_{m}=F(0) / 2^{m}(m=1,2, \cdots) .
$$

Proof. Since $F(t)$ is approximately continuous in $[0,1]$, we have that $f(t)$ has approximate limits everywhere. Thus

$$
F(t)=C \sum r_{m}(t) / 2^{m} \text { a.e., } C \text { being a constant. }
$$

But, since $\sum r_{m}(t) / 2^{m}=1-2 t$ a.e. (see [7, p. 220]), this implies that

$$
F(t)=C(1-2 t) \text { a.e. }
$$


which concludes our proof since $F(t)$ is approximately continuous.

REMARKs. 1. Corollary (2.2) shows that, if the approximate limits of $f(t)$ exist at certain dyadic rationals, then $a_{m}=C / 2^{m}$ for $m \geqq m_{0}$ (where $m_{0}, C$ are constants).

2. The conclusion of Corollary (2.3) was proved by Wang Si-Lei ([6, p. 704]; cf. [7, p. 221]) under the stronger hypothesis that $F(t)$ be continuous in $[0,1]$. Wang's result can also be obtained from Theorem (2.2) and Remarks (1) and (3) following it.

3. Corollary (2.2) is a generalization of some theorems of Wang [6, Th. 1, 2, 3].

4. In Corollary (2.3), the condition "convergent a.e." cannot be replaced by "convergent in $E \subset[0,1],|E|<1$ " [6, p. 706].

3. Variational properties. A. I. Rubinstein has shown $[4, \mathrm{p}$. 143] that if $\sum\left|a_{m}\right| 2^{m}<\infty$, then $f(t) \in \operatorname{Lip}(1,1)$.

In order to strengthen this result we now state the following lemma which follows from Minkowski's inequality:

Lemma (3.1). If $V_{p}\left(f_{m}\right)$ denotes the $p$ th variation of $f_{m}(t)$, then

(i) if $0<p \leqq 1, V_{p}^{p}\left(\sum_{m=1}^{\infty} f_{m}\right) \leqq \sum_{m=1}^{\infty} V_{p}^{p}\left(f_{m}\right)$;

(ii) if $p \geqq 1, V_{p}\left(\sum_{m=1}^{\infty} f_{m}\right) \leqq \sum_{m=1}^{\infty} V_{p}\left(f_{m}\right)$.

We will now prove

TheOREM (3.1). (i) If $0<p \leqq 1$, then $\sum\left|a_{m}\right|^{p} 2^{m}<\infty$ implies $f(t)$ is of bounded pth variation;

(ii) if $p \geqq 1$, then $\sum\left|a_{m}\right| 2^{m / p}<\infty$ implies $f(t)$ is of bounded pth variation;

(iii) if $0<p \leqq 1$, then $a_{m} \downarrow 0, \sum a_{m}^{p} 2^{m}=\infty$ implies

$$
g(t)=\sum(-1)^{m} a_{m} r_{m}(t)
$$

is not of bounded pth variation.

Proof. Parts (i) and (ii) are immediate by the lemma.

Also, setting $\left\{t_{i}\right\}=\left\{2^{-n-1}+i 2^{-n}\right\}_{i=0}^{2^{n-1}}$ and $b_{m}=(-1)^{m} a_{m}$ we obtain

$$
\begin{aligned}
& \sum_{i=1}^{2^{n-1}}\left|g\left(t_{i}\right)-g\left(t_{i-1}\right)\right|=\left|-2 b_{1}+\cdots+2 b_{n}\right|^{p} \\
& \quad+2\left|-2 b_{2}+\cdots+2 b_{n}\right|^{p}+\cdots+2^{n-2}\left|-2 b_{n-1}+2 b_{n}\right|^{p} \\
& \quad+2^{n-1}\left|2 b_{n}\right|^{p} \geqq \sum_{i=1}^{n} 2^{i-1}\left|2 b_{i}\right|^{p} \rightarrow \infty \text { as } n \rightarrow \infty .
\end{aligned}
$$


This demonstrates Part (iii).

4. Differentiability properties. With regard to differentiability, L. A. Balasov has shown $[1, \mathrm{p} .631]$ that $f(t)$ has a derivative at least one point if and only if

$$
\lim 2^{m} a_{m}=A \text { exists . }
$$

Balasov has demonstrated that this condition alone is not sufficient in order to have $f(t)$ differentiable a.e. [1, pp. 633-4]. He then proves that condition (3) and the relation

$$
a_{k} \geqq \sum_{m=k+1}^{\infty} a_{m} \text { for every } k \geqq 1
$$

implies $f(t)$ is monotone in $[0,1]$, which of course implies differentiability almost everywhere.

We now prove

Theorem (4.1). (i) If $\sum\left|a_{m}\right| 2^{m}<\infty$, then $f(t)$ is differentiable almost everywhere;

(ii) if $\left\{\varepsilon_{m}\right\}$ is any null sequence, then there exists a sequence $\left\{a_{m}\right\}$ satisfying

(a) $\sum\left|a_{m} 2^{m} \varepsilon_{m}\right|<\infty$,

(b) $f(t)=\sum a_{m} r_{m}(t)$ is differentiable nowhere.

Proof. Part (i) follows immediately from Theorem (3.1).

Part (ii). Since $\left\{\varepsilon_{m}\right\}$ is a null sequence, there exists an increasing sequence of positive integers $\left\{N_{m}\right\}$ such that

$$
\left|\varepsilon_{N_{m}}\right|<2^{-m}, \quad m=1,2, \cdots \text {. }
$$

Now set

$$
\begin{aligned}
a_{m} & =2^{-m}, \text { if } m=N_{i}, \quad i=2,4,6, \cdots \\
& =0, \text { otherwise. }
\end{aligned}
$$

Then (a) follows from condition (4), and (b) follows since Balasov's condition (3) for differentiability is not satisfied.

REMARK. It would be interesting to know if the sum, $f(t)$, of a Rademacher series is of bounded variation whenever $f(t)$ is differentiable almost everywhere (as is the case for lacunary trigonometric series). 


\section{REFERENCES}

1. L. A. Balasov, On series with gaps (Russian), Izv. Akad. Nauk SSSR Ser. Math. 29 (1965), 631-644.

2. S. Kaczmarz and H. Steinhaus, Le systeme orthogonal de $M$. Rademacher, Studia Math. 2 (1930), 231-247.

3. F. R. Keogh, On Rademacher series with bounded sums, J. London Math. Soc. 33 (1958), 454-455.

4. A. I. Rubenstein, On gap series (Russian), Izv. Ucebn. Zaved. Mat. 34 (1963), 137-148.

5. S. Saks, Theory of the Integral, Dover, New York, 1964.

6. Wang Si-Lei, On the functions represented by Rademacher series, Chinese Math. 4 (1963), 703-708=Acta Math. Sinica 13 (1963), 647-652.

7. S. B. Stechkin and P. L. Ul'janov, On uniqueness sets (Russian), Izv. Akad. Nauk SSSR Ser. Math. 26 (1962), 211-222.

8. A. Zygmund, Trigonometric Series, Vol. 1, Cambridge, New York, 1959.

Received June 27, 1967. This research was supported by a National Aeronautics and Space Administration Fellowship.

Wayne State University and Pennsyavania State university 


\section{PACIFIC JOURNAL OF MATHEMATICS}

\section{EDITORS}

\section{H. ROYDEN}

Stanford University

Stanford, California

\author{
R. R. Phelps \\ University of Washington \\ Seattle, Washington 98105
}

\section{J. DugundJI}

Department of Mathematics University of Southern California Los Angeles, California 90007

\section{RICHARD ARENS}

University of California

Los Angeles, California 90024

\section{ASSOCIATE EDITORS}

\section{E. F. BECKENBACH}

B. H. NEUMANN

F. WOLF

K. YOSIDA

\section{SUPPORTING INSTITUTIONS}

UNIVERSITY OF BRITISH COLUMBIA CALIFORNIA INSTITUTE OF TECHNOLOGY UNIVERSITY OF CALIFORNIA MONTANA STATE UNIVERSITY UNIVERSITY OF NEVADA NEW MEXICO STATE UNIVERSITY OREGON STATE UNIVERSITY UNIVERSITY OF OREGON OSAKA UNIVERSITY UNIVERSITY OF SOUTHERN CALIFORNIA

\author{
STANFORD UNIVERSITY \\ UNIVERSITY OF TOKYO \\ UNIVERSITY OF UTAH \\ WASHINGTON STATE UNIVERSITY \\ UNIVERSITY OF WASHINGTON \\ AMERICAN MATHEMATICAL SOCIETY \\ CHEVRON RESEARCH CORPORATION \\ TRW SYSTEMS
}

NAVAL WEAPONS CENTER

Mathematical papers intended for publication in the Pacific Journal of Mathematics should be in typed form or offset-reproduced, double spaced with large margins. Underline Greek letters in red, German in green, and script in blue. The first paragraph or two must be capable of being used separately as a synopsis of the entire paper. It should not contain references to the bibliography. Manuscripts, in duplicate if possible, may be sent to any one of the four editors. All other communications to the editors should be addressed to the managing editor, Richard Arens, University of California, Los Angeles, California 90024.

Each author of each article receives 50 reprints free of charge; additional copies may be obtained at cost in multiples of 50 .

The Pacific Journal of Mathematics is published monthly. Effective with Volume 16 the price per volume (3 numbers) is $\$ 8.00$; single issues, $\$ 3.00$. Special price for current issues to individual faculty members of supporting institutions and to individual members of the American Mathematical Society: $\$ 4.00$ per volume; single issues $\$ 1.50$. Back numbers are available.

Subscriptions, orders for back numbers, and changes of address should be sent to Pacific Journal of Mathematics, 103 Highland Boulevard, Berkeley 8, California.

Printed at Kokusai Bunken Insatsusha (International Academic Printing Co., Ltd.), 7-17, Fujimi 2-chome, Chiyoda-ku, Tokyo, Japan.

PUBLISHED BY PACIFIC JOURNAL OF MATHEMATICS, A NON-PROFIT CORPORATION

The Supporting Institutions listed above contribute to the cost of publication of this Journal, but they are not owners of publishers and have no responsibility for its content or policies. 


\section{Pacific Journal of Mathematics}

\section{Vol. 27, No. $2 \quad$ February, 1968}

Leonard E. Baum and George Roger Sell, Growth transformations for

functions on manifolds ............................ 211

Henry Gilbert Bray, A note on CLT groups ................... 229

Paul Robert Chernoff, Richard Anthony Rasala and William Charles

Waterhouse, The Stone-Weierstrass theorem for valuable fields....... 233

Douglas Napier Clark, On matrices associated with generalized

interpolation problems ................................

Richard Brian Darst and Euline Irwin Green, On a Radon-Nikodym theorem for finitely additive set functions . ...................... 255

Carl Louis DeVito, A note on Eberlein's theorem..................... 261

P. H. Doyle, III and John Gilbert Hocking, Proving that wild cells exist . . . 265

Leslie C. Glaser, Uncountably many almost polyhedral wild $(k-2)$-cells in

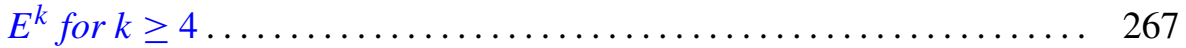

Samuel Irving Goldberg, Totally geodesic hypersurfaces of Kaehler

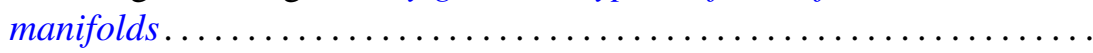

Donald Goldsmith, On the multiplicative properties of arithmetic functions .................................... 283

Jack D. Gray, Local analytic extensions of the resolvent ............ 305

Eugene Carlyle Johnsen, David Lewis Outcalt and Adil Mohamed Yaqub,

Commutativity theorems for nonassociative rings with a finite division ring homomorphic image ....................

André (Piotrowsky) De Korvin, Normal expectations in von Neumann

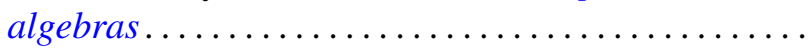

James Donald Kuelbs, A linear transformation theorem for analytic

Feynman integrals..........................

W. Kuich, Quasi-block-stochastic matrices ................... 353

Richard G. Levin, On commutative, nonpotent archimedean

semigroups ............................... 365

James R. McLaughlin, Functions represented by Rademacher series ... . . . 373

Calvin R. Putnam, Singular integrals and positive kernels............ 379

Harold G. Rutherford, II, Characterizing primes in some noncommutative

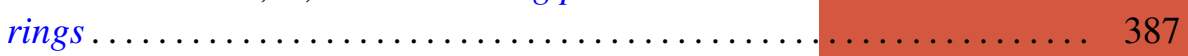

Benjamin L. Schwartz, On interchange graphs................... 393

Satish Shirali, On the Jordan structure of complex Banach *algebras . . . . . 397

Earl J. Taft, A counter-example to a fixed point conjecture............. 405

J. Roger Teller, On abelian pseudo lattice ordered groups ..... 